IZA DP No. 5100

Labor Market Policy: A Comparative View on the Costs and Benefits of Labor Market Flexibility

Lawrence M. Kahn

July 2010 


\title{
Labor Market Policy: A Comparative View on the Costs and Benefits of Labor Market Flexibility
}

\author{
Lawrence M. Kahn \\ Cornell University, \\ CESifo, NCER and IZA
}
July 2010
IZA
P.O. Box 7240
53072 Bonn
Germany

Discussion Paper No. 5100

Phone: +49-228-3894-0

Fax: +49-228-3894-180

E-mail: iza@iza.org

\begin{abstract}
Any opinions expressed here are those of the author(s) and not those of IZA. Research published in this series may include views on policy, but the institute itself takes no institutional policy positions.

The Institute for the Study of Labor (IZA) in Bonn is a local and virtual international research center and a place of communication between science, politics and business. IZA is an independent nonprofit organization supported by Deutsche Post Foundation. The center is associated with the University of Bonn and offers a stimulating research environment through its international network, workshops and conferences, data service, project support, research visits and doctoral program. IZA engages in (i) original and internationally competitive research in all fields of labor economics, (ii) development of policy concepts, and (iii) dissemination of research results and concepts to the interested public.
\end{abstract}

IZA Discussion Papers often represent preliminary work and are circulated to encourage discussion. Citation of such a paper should account for its provisional character. A revised version may be available directly from the author. 


\section{ABSTRACT}

\section{Labor Market Policy: A Comparative View on the Costs and Benefits of Labor Market Flexibility}

I review theories and evidence on wage-setting institutions and labor market policies in an international comparative context. These include collective bargaining, minimum wages, employment protection laws, unemployment insurance (UI), mandated parental leave, and active labor market policies (ALMPs). Since it is unlikely that an unregulated private sector would provide the income insurance these institutions do, these policies may enhance economic efficiency. However, to the extent that unemployment or resource misallocation results from such measures, these efficiency gains may be offset. Overall, Scandinavia and Central Europe follow distinctively more interventionist policies than the English speaking countries in the Northern Hemisphere. Possible explanations for such differences include vulnerability to external market forces and ethnic homogeneity. I then review evidence on the impacts of these policies and institutions. While the interventionist model appears to cause lower levels of wage inequality and high levels of job security to incumbent workers, it also in some cases leads to the relegation of new entrants (disproportionately women, youth and immigrants) as well as the less skilled to temporary jobs or unemployment. Making labor markets more flexible could bring these groups into the regular labor market to a greater extent, at the expense of higher levels of economic insecurity for incumbents and higher levels of wage inequality. The Danish model of loosening employment protections while providing relatively generous $\mathrm{UI}$ benefits with strict job search requirements holds out the possibility of reducing barriers for new entrants and the less skilled while maintaining some level of income insurance.

JEL Classification: J68

Keywords: labor market flexibility

Corresponding author:

Lawrence M. Kahn

Cornell University

258 Ives Hall

Ithaca, New York 14583

USA

E-mail: Imk12@cornell.edu

\footnotetext{
* The author thanks Andrea Bassanini and Pascal Marianna for helpful information about and supplying unpublished OECD data.
} 


\section{Introduction}

Persistently high unemployment rates in several European countries and relatively low wage levels among less skilled workers in the United States have led researchers and policymakers to seek policies to alleviate these twin labor market problems. Perhaps the key issue countries face in designing labor market policy is to determine the appropriate degree of labor market flexibility in wage setting, labor utilization (hiring, retention and assignment decisions by firms), and labor mobility. At one extreme stand the Scandinavian countries with very high levels of union coverage and extensive government intervention in the labor market. At the other extreme are English-speaking countries such as Canada, the United Kingdom, and the United States with low levels of union coverage and far less extensive welfare state protections and other labor market regulation systems. In this paper, I explore reasons for such differences and then provide a comparative analysis of the impact of labor market policy on outcomes such as unemployment, wage inequality, gender pay gaps, employment security and productivity. I will focus primarily on OECD countries with some additional discussion of specific policies in Latin America.

The paper will first provide comparative information on several dimensions of flexibility, including wage setting institutions (collective bargaining and minimum wage laws), employment protection mandates (e.g. mandated severance pay or restrictions on the use of temporary employment contracts), unemployment insurance (UI) benefit levels and duration, active labor market policy programs (ALMPs--e.g. public employment or training programs), and parental leave mandates. ${ }^{1}$ The next portion of the paper will discuss economic theory on the reasons why countries differ in their policy regimes and the expected impact of these labor market policies on outcomes such as wage inequality, unemployment, and the incidence of temporary employment. This discussion will emphasize the potential benefits of labor market policies in solving market

\footnotetext{
${ }^{1}$ While collective bargaining is not a government program, it interacts with labor market policies in ways I will discuss in detail. Moreover, government policy can have a direct impact on the level and type of collective bargaining coverage through mandated representation procedures as well as government policies extending collective bargaining agreements to nonunion workers.
} 
failures that an unregulated labor market may produce, such as an incomplete market in income insurance. On economic theory and expected effects of labor market policies, an important theme is the interaction between wage rigidity (i.e. a lack of responsiveness of wages to market forces) and labor market policies such as mandated employer-paid benefits (including employment protection or employer-paid fringe benefits), as well as potential interactions between the policies themselves.

The next section will provide some descriptive information on labor market performance among some major OECD countries including relative unemployment by groups (e.g., gender or nativity), the incidence of temporary employment contracts, wage inequality overall, and the gender pay gap. The paper will then present evidence on the impact of labor market policies on these outcomes. I will discuss some methodological issues in assessing these effects, including the need to take into account population heterogeneity, the likely interaction between policies, and the endogeneity of policy decisions. Finding appropriate research designs to allow one to make causal statements is the central research issue facing those who wish to evaluate labor market policies, and I will provide examples of such designs.

The paper then summarizes evidence on the impact of several important labor market policies and institutions on unemployment, relative wages, the gender pay gap, the incidence of temporary employment, and productivity. I specifically consider evidence on wage-setting institutions such as collective bargaining and minimum wages, as well as unemployment insurance (UI), employment protection mandates, parental leave, and active labor market policy (ALMP). Some of the most convincing research designs in this area involve instances where one country has enacted a reform (e.g. of its UI or employment protection systems) affecting particular subgroups of the population such as older workers. These instances help provide researchers with appropriate control groups and may address the endogeneity problem just mentioned, and such analyses are at the forefront of empirical economic research on the impact of labor market policy. 


\section{International Differences in Wage-Setting Institutions and Labor Market Policies}

Tables 1-3 provide some descriptive information on the dramatically different labor market institutions and policies across some major OECD countries. The countries chosen can be grouped as Scandinavian (Denmark, Finland, Norway and Sweden), Central European (France, Germany, Italy and Spain), and English-speaking (Canada, the United Kingdom, and the United States). Scandinavian countries stand out as having chosen very extensive interventions in their labor markets, while the English-speaking countries have the least intervention and are the most flexible along the dimensions mentioned earlier. The Central European countries resemble Scandinavia more than the English-speaking countries; moreover, the four listed have relatively large populations and thus represent an important share of Europeans. $^{2}$

Table 1 provides information on collective bargaining institutions. The Scandinavian countries exhibit high levels of both union membership and collective bargaining coverage; moreover, wage setting is relatively coordinated in these countries as well, with many agreements fashioned at the sectoral level or even higher. Government policy can influence coordination through policies on wage negotiations as occurred in Norway's recentralization in the late 1980s (Kahn 1998). Union density in Scandinavia ranges from 54\% to 79\%, while coverage goes from a minimum of over $70 \%$ to over $90 \%$. The Central European countries have much lower union membership levels (10-35\%) but similar coverage rates by collective bargaining to Scandinavian levels. This difference between membership and coverage is due in an accounting sense to government policies in all four of these countries to extend the terms of collective bargaining agreements to nonunion workers (OECD 2004, p. 148). The prevalence of such policies in fifteen OECD countries represents a potentially important impact of labor

\footnotetext{
${ }^{2}$ For example, France, Germany, Italy and Spain comprise $78 \%$ of the population of the EU-15 countries (see the Eurostat website:

http://epp.eurostat.ec.europa.eu/tgm/table.do?tab=table\&language=en\&pcode=tps00001\&tableSelection $=1 \&$ footnot $\underline{\text { es=yes\&labeling=labels\&plugin }=1}$. )
} 
market policy. ${ }^{3}$ Wage setting is relatively coordinated in the Central European countries, particularly in Italy and Germany. Finally, the English-speaking countries have low levels of membership and coverage, and very decentralized wage setting. The United States stands out with the lowest levels of coverage at $14 \%$. Thus, on wage-setting institutions, the Englishspeaking countries allow much more flexibility than those in Continental Europe.

A major labor market policy is mandated employment protection. This concept encompasses a variety of rules including mandated severance pay in the event a firm fires a worker, administrative procedures including the requirement to negotiate over reductions in force, mandatory notice periods before layoffs, and limitations on the use of temporary employment contracts (OECD 2004, pp. 61-125). The OECD has aggregated these provisions into indexes of protection on regular jobs (based on policies such as mandatory severance pay) and temporary employment (comprising regulations such as the maximum number and duration of such contracts), and Table 2 summarizes these indexes for the 11 countries shown in Table 1. Overall, the Scandinavian and Central European countries have far more extensive protections on regular jobs and more restrictions on the use of temporary contracts than the English-speaking countries do. Sweden, Spain and Germany have particularly strong protections on regular jobs, while France and Spain have the strictest rules on temporary contracts. Among the Continental European countries, Denmark stands out as having the weakest protections, a theme I will discuss later, although even Denmark's regulations are stricter than those in the English-speaking countries. Denmark's system of employment regulation has been dubbed a "flexicurity" policy, in which firms have flexibility to fire workers, and workers have income security through the UI system (Anderson and Svarer 2007). As was the case with wage setting, the English speaking countries allow firms the most freedom, in this instance the freedom to fire workers from regular jobs and to use temporary employment contracts. The US again stands out as having the least regulation of its labor market with respect to employment protection.

\footnotetext{
3 In addition to France, Germany, Italy and Spain, the government can extend the terms of collective bargaining agreements to nonunion workers in Australia, Austria, Belgium, Finland, Greece, Hungary, the Netherlands, Poland, Portugal, the Slovak Republic, and Switzerland (OECD 2004, p. 148).
} 
Table 3 provides information on several other important elements of labor market policy. The pattern of greater intervention in Continental Europe, particularly Scandinavia, than in the English-speaking countries continues. Specifically, UI benefit levels and potential duration are far more generous in Scandinavia and France than elsewhere, and with the exception of Italy, are weakest in the English-speaking countries. Denmark stands out as having a high replacement rate and the longest potential duration, the "security" portion of its flexicurity policy. Of the countries with statutory minimum wages, France has the highest relative level, although in several countries without statutory minima, unions negotiate sectoral minimum wages (for example in Scandinavia and Germany). Continental European countries spend much higher portions of their GDP on ALMPs than the English-speaking countries do, particularly Denmark and Sweden. These policies include training programs, employment subsidies, and direct job creation through public employment and represent an important aspect of labor market policy (OECD 2010, pp. 298-304). Finally, overall, Continental European countries mandate relatively high levels of paid parental leave, particularly Norway, Sweden and Germany, although Canada's level is higher than several European country levels. Parental leave can be seen as a labor market policy in that it provides incentives to leave the labor force during child rearing but also allows one to maintain ties to the firm on returning to work. ${ }^{4}$

\section{Economic Theory on Reasons for and Effects of Labor Market Policies}

Several of the policies and institutions described in Tables 1-3 provide some form of income insurance. Specifically, as discussed further below, centralized collective bargaining agreements reduce wage differentials, lowering employed workers' uncertainty over earnings both over time and also across workers at a point in time (Agell and Lommerud 1992); moreover, employment protection directly insures workers' jobs, UI is explicitly an insurance program, and ALMPs and parental leave also provide insurance against economic fluctuations

\footnotetext{
4 Although the US doesn't require any paid parental leave, its 1993 Family and Medical Leave Act provides a mandated twelve weeks of unpaid leave, a policy designed to allow workers to maintain ties with their firm (Blau, Ferber and Winkler 2010, p. 186).
} 
and family-related disruptions of work. Because of problems of adverse selection and moral hazard, private, unregulated markets are not likely to provide economically efficient levels of income insurance. ${ }^{5}$ Thus, there is likely to be an efficiency role for public policy in this area, in the sense that the government can provide a product that people desire and are willing to pay for but that the private sector will not supply. Of course, even if there were no efficiency gains caused by government policy in these areas, political coalitions such as currently employed workers might push for protections that benefit them, perhaps to others' detriment (Brügemann 2007).

While insurance motives may help explain why governments enact certain labor market policies, what explains the differences in regulatory systems we see in Tables 1-3 such as the relatively heavy reliance on such interventionist policies in Scandinavia and light regulation in the English-speaking countries? A detailed analysis of this topic would take us into areas of political economy that are beyond the scope of this paper. However several hypotheses have emerged from economists and political scientists that help explain the variety of policy outcomes we see in Tables 1-3. First, according to Rodrik (1998), one of the major motivations for public services (such as active labor market policies) is to provide social insurance that the private market is unwilling or unable to provide. He hypothesizes and finds that countries that are most susceptible to external risk (caused by exogenous factors leading to openness to international trade) will, other things equal, have larger public sectors. Similar ideas can be found in the political science literature as well (Cameron 1978; Katzenstein 1985). Second, ethnic homogeneity may lead to national consensus in providing public goods such as those supplied by social insurance programs (Alesina and Glaeser 2004), and Scandinavia may fit this bill better

\footnotetext{
5 Adverse selection occurs when people with the highest risks of needing insurance disproportionately decide to buy it, and moral hazard occurs when insurance causes people to behave in ways that increase their use of insurance. An example of the former could be when workers anticipating layoff decide to buy a hypothetical income insurance policy, while an example of moral hazard could be when the presence of unemployment insurance causes workers to stay unemployed longer. These two phenomena are likely major reasons why the private sector does not offer much in the way of income insurance. In addition, since unemployment often affects a whole country, a private insurance company might not be able to pool income risks and therefore would be unlikely to offer income insurance. For further discussion of the issues, see Rothschild and Stiglitz (1976).
} 
than the US, the UK or Canada. A related hypothesis comes from Summers, Vergara and Gruber (1993) who suggest that countries with very centralized and strong labor movements may be better able to follow a high tax, high social benefit policy because the major decision makers, centralized trade unions, can internalize the possible disincentive effects of high taxes by controlling labor supply. While each of these explanations may have some merit, this is an area of ongoing research as investigators seek to explain why labor market policies differ across countries.

On the effects of labor market policies, a basic prediction from microeconomics is that union wage setting will lower employment if labor markets would otherwise be competitive and if firms are allowed to hire as much or as little labor as they want (the so-called "right to manage model"). ${ }^{6}$ Moreover, if unions reduce the responsiveness of wages to economic conditions, then demand shocks to the economy will lead to larger aggregate employment fluctuations in unionized than in nonunion labor markets (Blanchard and Wolfers 2000). To some degree these adverse macroeconomic effects can be alleviated under highly coordinated bargaining, as centralized unions may be able to anticipate the macroeconomic effects of their wage bargains in ways that decentralized unions may not; this phenomenon may have helped explain low unemployment in some of the highly unionized Scandinavian countries (Calmfors and Driffill 1988; Nickell and Layard 1999).

As discussed by Bertola (1992), the overall employment effects of employment protection mandates are theoretically ambiguous, since such laws deter both job destruction (by inducing firms to keep workers they would otherwise fire) and job creation (as firms anticipate that they might have to fire newly hired workers some time in the future). But the negative effects on employment are most likely to be felt by new entrants, while the positive effects are felt by incumbents. We therefore predict that employment protection will lower the relative

\footnotetext{
${ }^{6}$ This prediction becomes less firm if labor and management jointly set wages and employment or if firms have monopsony power in the labor market. For discussion of these issues, see Farber (1986) and Manning (2003).
} 
employment levels of the less experienced, including youth, women and immigrants (Kahn 2007).

An important insight on the economics of employment protection comes from the work of Lazear (1990) who suggests that if wages are flexible, then mandating employment protection in the form of severance pay to workers should lead to lower wages, as the demand for labor shifts down. If so, then employment protection need not lead to higher overall labor costs to firms and thus not to a lower overall demand for labor. This reasoning is an example of the more general phenomenon of mandated employer-provided benefits such as health care, family leave, or pensions. Specifically, if the government requires firms to pay for such benefits and if workers value them by as much as they cost, then both the supply and demand curves for labor will shift down equally, leaving employment unchanged if wages are flexible (Summers 1989).

The foregoing analysis implies that wage rigidity and mandated benefits will have interaction effects. If, for example, unions have reduced or eliminated the effect of market forces on wages, then mandated benefits will have more negative employment effects than otherwise (in the same manner as in Blanchard and Wolfers' (2000) discussion of macroeconomic shocks, mentioned earlier). Unions have been shown to compress wages, particularly at the bottom of the wage distribution, through standard rate policies and coordinated wage policies in highly unionized countries such as those in Scandinavia (Freeman 1982; Blau and Kahn 1996; Wallerstein 1999; Edin and Topel 1997; Koeniger, Leonardi and Nunziata 2007). Thus, mandated benefits will lower the relative employment of low wage workers by more in countries with highly centralized, compressed wage structures than in nations with more wage inequality. Moreover, my earlier discussion of new entrants vs. incumbents and employment protection implies that protection will raise the employment gap by more the more compressed the wage structure is. Thus, we predict that mandated benefits such as employment protection will tend reduce the ability of low wage workers and new entrants to obtain high-paying, protected jobs by more when the wage structure is highly compressed (Kahn 2007). 


\section{Labor Market Performance in Selected OECD Countries}

Tables 4-7 provide some descriptive information on labor market performance across the eleven countries studied in Tables 1-3. Table 4 shows various measures of labor utilization, including employment to population ratios, part time employment incidence and unemployment rates. Looking first at overall employment, Denmark and Norway have relatively high levels of male and female employment, while they are low in Spain and Italy. Differences across countries in employment are larger for older and younger individuals than for those of prime age (ages 25-54). For example, France, Spain and Italy have especially low levels of employment among both youth and older men and women, and older and younger men have especially low employment to population ratios in Finland. Among employed women, part-time jobs are especially prevalent in Germany, Italy, the UK, and Norway but much less so in Finland, Sweden and the United States. While part-time work is of course much less prevalent for men, Denmark has a relatively high incidence of male part time employment, and part-time work is particularly rare among Italian and Spanish men.

Table 4 also shows unemployment rates for 2009 by age and gender, which have risen sharply during the recession of 2008-9. For example, across the OECD, unemployment rose from $5.6 \%$ in late 2007 to $8.5 \%$ in the first quarter of 2010 (OECD 2010, p. 19). Table 4 shows that overall unemployment for the full age range (15-64 years) is very high in Spain for both men and women (17.8-18.5\%), while it is very low in Norway (2.7-3.7\%), with Denmark having the next lowest unemployment at 5.4-6.7\%. ${ }^{7}$ Moreover, youth unemployment is higher than adult unemployment in each country, with especially high levels in Spain, France, Sweden, Finland and Italy, and low levels in Denmark, Germany and Norway. The English-speaking countries have intermediate levels of youth unemployment.

\footnotetext{
7 Unemployment has risen especially sharply in Spain and the United States, which had severe real estate crises (OECD 2010, p. 17). For example, between 2007 and 2009, overall unemployment rose from 8.5 to $18.0 \%$ in Spain and from 4.6 to $9.3 \%$ in the US.
} 
The 2008-9 recession has raised male unemployment by more than female unemployment. For example, in our sample of 11 countries, between 2007 and 2009, male unemployment rose by an unweighted average of 3.3 percentage points (from 5.7 to 9.0), while women's unemployment rose by only 1.7 percentage points (from 6.5 to 8.2 ); thus, overall, the gender gap in unemployment reversed between these two years, moving from a female excess of 0.8 percentage points to a male excess of 0.8 percentage points. ${ }^{8}$ In Scandinavia, men's unemployment was 0.5 percentage points less than women's in 2007 , while it was 1.1 percentage points higher than women's by 2009; in the Central European countries in Table 4, male unemployment was 2.2 percentage points lower than women's in 2007; however, the excess female unemployment there had shrunk to 0.7 percentage points by 2009 . And in the English speaking countries, women actually had lower unemployment than men in 2007 with a margin of 0.5 percentage points; by 2009, men's excess unemployment in these nations had risen to 2.4 percentage points. Thus, in both years, women had lower relative unemployment in the Englishspeaking countries than in Continental Europe.

Table 5 compares unemployment rates by immigrant status and gender for 2007 , the most recent year for which such a breakdown can be constructed. In the Continental European countries, unemployment is always higher for immigrants than natives, with especially large gaps in all of the Scandinavian countries and in France and Germany. For example, among these six countries, the gap for men ranges from 4.7 (France) to 7.2 (Germany) percentage points, while for women, immigrant unemployment is higher than the level for natives by 4.1 (Denmark) to 10.5 (Finland) percentage points. These are very large differentials and suggest that immigrants have considerably more difficulty finding work than natives do in these countries, even when as in the cases of Denmark and Norway, the overall unemployment rate is relatively low. The English-speaking countries are notable in that immigrant unemployment is usually similar to native unemployment, with the exception of immigrant women in the UK, whose unemployment is 4.1 percentage points above natives'. But for Canada, the US and British men,

${ }^{8}$ See OECD (2010), pp. 272-3. 
immigrant unemployment is far less different from natives' level than it is in the other European countries. In fact, for Canadian men and both men and women in the US, immigrant unemployment is actually slightly lower than native levels. Notably, although native unemployment is higher in the US than in Denmark or Norway, the rate for immigrant men and women is considerably higher in the latter two countries.

While lower unemployment rates typically mean a more successful level of labor market performance, not all jobs are equally valuable. As discussed further below, one of the most common labor market policies pursued by European countries seeking to fight high unemployment levels without threatening the protections illustrated in Tables 1-3 is to allow firms greater freedom to create temporary jobs. Such jobs are known to pay less, offer less training, and be less satisfying than regular jobs (Booth, Francesconi and Frank 2002; Kahn 2007). On the other hand, it is possible that such jobs may be stepping stones to regular employment, although evidence on this issue is mixed (Booth, Francesconi and Frank 2002; Autor and Houseman forthcoming; and Ichino, Mealli, and Nannicini 2005). Table 6 shows the incidence of temporary employment by gender and age for 2000, and the overall incidence, plus that for women, youth and those age 25-54 in 2009. The overall incidence of temporary employment in both years is much higher in Spain than elsewhere; moreover, it is also high in Finland, Sweden, France and Germany and low in the UK and the US in both years.

Women have higher levels of temporary employment than men in each case except for the US in 2009, where the average and the female rates are the same. ${ }^{9}$ The gender gap in 2000 was usually lower in the English-speaking countries (with women having an incidence 0.3 to 1.8 percentage points higher than men's) than in the Continental European countries (0.6 to 6.4 percentage points), and, similarly, in 2009, the difference between women's rate and the overall rate of temporary jobs was smaller in the English speaking countries ( 0.0 to 0.4 percentage points) than in Continental Europe (0.1 to 3.9 percentage points). The 2009 comparison between the Total and Women in Table 6 of course doesn't control for the relative size of female

\footnotetext{
${ }^{9}$ The OECD didn't report the separate male incidence for 2009.
} 
employment in affecting the total, while in 2000, the OECD's figures allow a sharper gender comparison. Nonetheless, the overall conclusion on gender and temporary employment is similar for 2009 as for 2000: in the English speaking countries, the gender gap in the incidence of permanent employment is lower than in Continental Europe.

Young people everywhere are more likely to be in temporary jobs, with especially high levels in Spain, Finland, France, Sweden and Germany, and low levels in the UK and the US. Thus, overall, temporary employment seems lower in the countries with fewer restrictions on their labor markets, and new entrants do relatively better in finding permanent jobs in these countries as well. Of course, the permanence of permanent jobs may be less evident in the English-speaking countries as well, due to lower mandated levels of employment protection. Thus, age and gender gaps in mandated employment security are likely to be lower in the English-speaking countries both because young workers and women have a higher relative incidence of permanent employment there and because permanent employment provides less mandated protection there than in Continental Europe.

Table 7 shows data on wage inequality and the gender pay gap. Pay inequality between the high end $\left(90^{\text {th }}\right.$ percentile $)$ and the middle $\left(50^{\text {th }}\right.$ percentile $)$ is especially high in the US, Spain, France, the UK and Canada, while it is relatively low in Sweden and Norway. The bottom is less compressed (i.e. the 50-10 gap) in the US, Canada, Germany and the UK, while it is especially tightly compressed in Scandinavia, France and Italy. Finally, the gender pay gap is especially low in France, Italy, Norway, Spain, and Denmark, and is highest in Germany. But overall, the differences in the gender pay gap across countries are not nearly as large as the differences in the 50-10 or 90-50 pay gaps. Specifically, the ratio of female to male full time earnings ranges from 0.75 (Germany) to 0.94 (Italy), while the 50-10 and 90-50 ratios range from 1.37-2.09 (50-10) and from 1.46-2.34 (90-50). ${ }^{10}$ I note that in the 1980s, there were far larger international

\footnotetext{
10 The OECD Employment Outlook for 2010 reports an Italian gender pay of only 1\% (p. 295), when people selfreport their full-time status rather than their actual work hours. This figure is somewhat smaller than recent research on the gender pay gap in Italy has found. For example, several authors have reported gender pay gaps for Italy ranging from 4\% to 6\% over the 1995-2005 period such as: Olivetti and Petrongolo (2008), p. 632; Arulampalam, Booth and Bryan (2007), p. 166; Picchio and Mussida (2010), p. 13; and OECD (2008), p. 146. Unpublished
} 
differences in the gender pay gap, and these have converged considerably (Blau and Kahn 1992;

2008). Overall, Table 7 shows that gender pay gap in the English speaking countries tends to be on the high side (the gap is $20-21$ percentage points) compared to the Continental European countries (where the gap is 6-25 percentage points).

Considering Tables 1-7 overall, it appears that the English-speaking countries have more flexible labor markets, as well as lower relative female and usually immigrant relative unemployment as well, lower incidence of temporary employment overall and among women and youth, and higher levels of wage inequality. While it is tempting to conclude that these differences in regulatory rules and institutions caused the differences in outcomes, we need to consider other possible causes of labor market outcomes; in addition, one must determine whether, after accounting for other factors, any remaining association between policies and outcomes is causal. The next section explores such issues and summarizes research findings on the impact of labor market policy on employment and wage outcomes.

\section{The Impact of Labor Market Policy on Labor Market Performance}

In order to detect the influence of policies on labor market outcomes researchers have had to confront several issues that prevent one from making conclusions based on simple crosssectional comparisons of the policies shown in Tables 1-3 and the outcomes depicted in Tables 4-7. First, some countries have a more diverse population with respect to their skills and ethnicity than others, although educational and immigration policies can affect such diversity. For example, it is possible that diversity of skills helps explain the higher US levels of wage

\footnotetext{
tabulations from the OECD, kindly supplied by Pascal Marianna, show a 6\% gap when full-time work is defined as usually working at least 30 hours per week. I use this estimate, which is still quite small by international standards. Earlier research also found a lower Italian gender pay gap than in most other Western countries (Blau and Kahn 2003). This low gap may be partially explained by Italian's relatively low employment rate (see Table 4 above), either through selection effects (Olivetti and Petrongolo 2008; Picchio and Mussida 2010) or a possible combination of selection effects and the impact of low female supply on female relative wages (Blau and Kahn 2003). Of course, to the extent that the low gender pay gap in Italy is caused by wage compression due to collective bargaining, some of women's low employment level in Italy may be a demand response by Italian employers.
} 
inequality shown in Table 7 (Blau and Kahn 2005). Second, Tables 1-3 show that some policies occur as a group. For example, the Scandinavia countries have high levels of collective bargaining coverage, strict employment protection and generous UI systems. It may be difficult to disentangle the influence of any one policy. Moreover, some policies may interact, as in the case of wage floors (fostered, for example, in France, Germany, Italy and Spain by government extension of collective bargaining agreements to nonunion workers) and employment protection mandates discussed earlier. Thus, the impact of employment protection is likely to be different in different countries. Third, some policies are enacted in response to employment problems. For example, it is likely that high unemployment in the 1990s induced a number of countries to ease restrictions on firms' right to create temporary jobs, in an attempt to increase job creation (Kahn 2010). One might therefore observe a positive correlation between unemployment rates and such reforms that doesn't reflect the reforms' true impact.

To deal with these research issues, several of the most successful studies of the impact of policy use data on individuals (allowing one to control for population heterogeneity). In addition, in some instances, there have been dramatic shifts affecting only one policy, allowing one to focus on a particular law. Moreover, policies have sometimes been enacted that affect subgroups differently, allowing one to form appropriate control groups in evaluating the impact of policies. These will be discussed below. The following review of evidence focuses on the impact of major labor policies in the areas of minimum wages and union wage-setting, employment protection, parental leave mandates, active labor market policies, and UI.

\section{A. Wage Setting Institutions}

Research on union wage setting and minimum wages robustly finds that these labor market institutions compress wages, particularly at the bottom of the pay distribution. These findings are obtained using aggregate data (e.g. Wallerstein 1999; Koeniger, Leonardi and Nunziata 2007) as well as individual-level data (Blau and Kahn 1996 and 2005; Dolado et. al 1996; Card and Krueger 1995; DiNardo, Fortin and Lemieux 1996). Moreover, several studies 
of changes in collective bargaining institutions within a single country find that increased centralization lowers wage inequality, including the cases of Sweden's solidarity wage policy of 1968-74 (Edin and Topel 1997; Davis and Henrekson 2005), Norway’s bargaining recentralization of 1988 (Kahn 1998), Italy's wage indexation policy of 1975-92 (Erickson and Ichino 1995; Manacorda 2004); and New Zealand's Employment Contracts Act of 1991, which greatly decentralized wage-setting there (Dixon 1998). However, research findings on the employment effects of such interventions are mixed. In some cases, the wage compression is seen to lower less skilled workers' relative employment, including the cases of Sweden and Norway just mentioned, as well as minimum wages and the employment of low-skill workers in France (Abowd et. al 2000) and Colombia (Bell 1995). In addition, unionized wage setting across the OECD has been found to lower the relative employment of women and youth, other things equal (Bertola, Blau and Kahn 2007). Some other studies, however, find that wage compression does not lower the relative employment of the less-skilled, including the cases of union wage setting in Canada, France, and Germany (see Card, Kramarz and Lemieux 1999 for a comparison of these three countries and Krueger and Pischke 1998 for a US-Germany comparison), and minimum wages in the US and the UK (Card and Krueger 1995; Machin and Manning 1994). In some cases, public employment has been credited with reducing the disemployment effects of wage compression (Edin and Topel 1997; Bjorklund and Freeman 1997; Kahn 1998; Blau and Kahn 2000; and Kahn 2008). In others, authors have found evidence suggesting that unions or minimum wages may act to counter employer market power and not lead to lower employment, as would have been expected under competitive labor markets (Card and Krueger 1995; Manning 2003).

\section{B. Employment Protection Mandates}

Employment protection is a major issue in labor market policy in Europe. Research on the effects of such mandates has examined both macroeconomic and individual worker and firm 
outcomes. At the macro level, Nickell and Layard (1999) found that in the 1980s and 1990s, strictness of protection on regular jobs across OECD countries was not correlated with overall unemployment rates, although as mentioned below, there is some evidence that employment protection has lowered employment in the US. There was, however, a positive association with long term unemployment that was counterbalanced by a negative association with short term unemployment. These offsetting results likely reflect the idea that protection deters both job creation (leading to a longer duration of unemployment for those looking for work) and job destruction (leading to fewer short term layoffs). Also at the macro level, Booth, Dolado and Frank (2002) found a positive association across OECD countries between the strictness of employment protection mandates and the incidence of temporary employment. The creation of temporary jobs is a predictable response by firms to high costs of downsizing permanent jobs.

At the individual worker level, Kahn (2007) found across several OECD countries in the 1990s that stricter permanent employment protection led to a higher relative incidence of temporary employment among women, youth and immigrants, with larger effects observed in countries with higher levels of collective bargaining coverage. This combination of findings suggests that wage floors interact with protection mandates to disproportionately shut out these groups from permanent, protected jobs.

Several authors have estimated the impact of recent reforms in employment protection systems in Europe or Latin America, with most analyses focusing on a specific country. In some of these cases, reforms were targeted at subgroups in the labor force, providing researchers with a natural experiment in which outcomes can be compared across subgroups. In each of these cases, the reforms were correlated with the expected changes in labor market outcomes, suggesting a policy impact. For example, in the non-targeted reforms (i.e. which applied to all employers and workers), transitions from temporary to permanent employment in France fell in the 1990s after firing costs from temporary jobs were lowered (Blanchard and Landier 2002); and in Italy, temporary employment grew in the late 1990s after passage of reforms making it easier to create temporary jobs (Boeri and Garibaldi 2007). Among the targeted reforms (i.e. 
those that applied to a subset of firms or workers), shortening the probationary period (during which workers may not sue for unfair dismissal) from two years to one year in the UK was associated with a decrease in the firing hazard for workers with up to two years of tenure relative to those with more tenure (Marinescu 2007). Moreover, in Colombia, after reforms reducing dismissal costs in the formal sector, labor market turnover into and out of unemployment rose in the formal sector relative to the informal sector (Kugler 1999). And the Spanish reforms of 1997 lowering dismissal costs for older and younger workers were associated with a relative increase in permanent employment for these groups (Kugler, Jimeno and Hernanz 2005). Further, the Italian reform of 1990 raising dismissal costs for firms with fewer than 15 workers was associated with reduced accessions and separations for these firms relative to larger firms (Kugler and Pica 2008). Finally, Kahn (2010) notes that the most common reform in the 1990s in Europe was to make it easier to create temporary jobs. He found that such reforms led to an increase in the incidence of such jobs but no increase in overall employment, suggesting that the reforms in effect encouraged the substitution of temporary for permanent jobs.

While overall the US has the weakest system of employment protection, there is variability across states in workers' rights to sue their firm over dismissals. Autor, Kerr and Kugler (2007) use this variation to study the impact of protection on productivity. The authors find that giving the workers the right to sue over dismissal leads to capital deepening (and presumably higher labor productivity) but lower total factor productivity (i.e. productivity given the level of labor and capital inputs). Moreover, MacLeod and Nakavachara (2007) find that such protection in the US leads to the use of more skill- and training-intensive production techniques. Both studies suggest that protection leads firms to economize on labor costs, but Autor, Kerr and Kugler's (2007) results suggest that less efficient techniques of production are used as a result. Moreover, Autor, Donohue and Schwab's (2006) finding that these state court decisions reduced overall employment is consistent with the idea that that they induce firms to economize on labor costs. 


\section{Parental Leave}

Parental leave mandates give parents an entitlement to their jobs and also in some cases provide pay while one is bearing or rearing children and not at work. Such mandates have a complicated set of potential effects on parents' labor market outcomes, and these impacts are disproportionately felt by women, under a traditional division of labor in the family. On the one hand, having an entitlement to one's job may raise incentives to return to work after childbearing; however, the availability of paid leave or a longer duration of potential leave may induce one to stay out of work longer than otherwise. ${ }^{11}$ Moreover, the benefits can only be taken if one was in a paid job to begin with; therefore the program may induce labor force entry before childbearing. Ruhm (1998) studied the impact of changes in paid parental leave mandates across nine European countries over the 1969-93 period. He found that the entitlement raised women's labor supply but that if paid leave was available for a long duration (e.g. 3 years), then the policy lowered their relative wages. The latter effect may have been due to a loss of women's human capital, the induced entry of less experienced women, or the costs imposed on firms by the requirement to keep the worker's job available (see my earlier discussion of mandated benefits and flexible wages). Thus, the impact of parental leave on women's employment should vary with the degree of wage flexibility, and this would be a fruitful area of further research.

While Ruhm (1998) studied nine European countries, Scandinavia is of special interest because it has the most generous parental leave and most extensive public child care availability among OECD countries. ${ }^{12}$ Datta Gupta, Smith and Verner (2008) review studies of these countries' policies and conclude that while they help explain Scandinavian women's relatively high labor force participation rates (see Table 4 above), they also hinder women's relative wages and occupational progression. Parental leave entitlement may lead to statistical discrimination

\footnotetext{
${ }^{11}$ Indeed, studies of the impact of lengthening the available time of mandated parental or maternity leave in Canada, Germany, and the US all find that such expansions increase the amount of time that mothers stay out of the paid labor force following childbirth. See Ondrich, Spiess, Yang and Wagner (2003), Han, Ruhm and Waldfogel (2007), and Baker and Milligan (2008).

${ }^{12}$ Of course, four of Ruhm's (1998) countries were Scandinavian (Denmark, Finland, Norway and Sweden), in addition to the others in his sample (Austria, Belgium, Portugal, Spain and UK).
} 
by firms to the extent that women disproportionately take the benefit. These findings are consistent with Ruhm (1998) employment and wage results.

\section{Active Labor Market Programs (ALMPs) and Unemployment Insurance (UI)}

All countries have policies to improve the labor market outcomes of the unemployed. These typically take the form of training, job search assistance or subsidized private or public employment. While there have been hundreds of studies evaluating such programs, Card, Kluve and Weber (2009) provide an excellent summary of 97 such studies which have appeared since 1996. Twenty six countries are represented in the authors' survey, and roughly $4 / 5$ of the estimates come from programs designed to improve the earnings and employment of unemployed workers. Job search assistance programs are found to have relatively positive effects in the short run, with classroom and on-the-job training programs having more positive medium term effects. Notably, subsidized public employment schemes have the least favorable effects. As the authors acknowledge, these estimates do not take into possible displacement effects of program participation: it is possible that a program finds someone a job at the expense of a non-participant. Forslund and Krueger (1997), for example, find evidence of such displacement effects in the Swedish context. And Algan, et al. (2002) find that public employment has adverse effects on the private sector economy. On the other hand, as noted earlier, public employment has been credited by some with helping to cushion the loss of jobs caused by high wage floors, a conclusion that appears to contradict Card, Kluve and Weber's (2009) survey of ALMPs. It is possible that the government serves as an employer of last resort even if such employment is not part of a formal ALMP, and even if as Algan, et al. (2002) find, private sector employment is indirectly hurt, the overall differential in employment between skilled and unskilled workers may be lower as a result.

UI programs provide benefits to qualifying unemployed workers. A robust finding across countries is that more generous UI benefits and longer potential duration of benefits at least 
modestly increase unemployment duration in the US, the UK and Germany, with larger effects in Sweden (Atkinson and Micklewright 1991; Hunt 1995; Carling, Holmlund and Vejsiu 2001). If this increased unemployment duration were used in productive search, it might lead to a more efficient allocation of labor resources in the economy. Unfortunately, there is little evidence that more generous UI benefits improve post-unemployment earnings (Ehrenberg and Smith 2006, p. 530). Perhaps because of such findings, states in the US and countries such as Denmark have experimented with their UI systems to encourage better matches with future employers. In the US, a series of experiments largely in the 1980s offering job-seeking services to a control group of UI recipients led to better matches, although in one experiment in 1994, such a treatment did not affect employment or earnings (Meyer 1995; Klepinger, Johnson and Joesch 2002). In Denmark, increased job search requirements have been credited with helping to lower that country's unemployment rate to the modest levels shown in Tables 4 and 5 above (Anderson and Svarer 2007). But such reforms of UI systems suggest the possibility that one could provide income security and perhaps improve the efficiency of the labor market at the same time.

Even if UI does lead to longer unemployment duration without better post-unemployment matches, the benefits of the insurance could outweigh such costs. Gruber (1997) in fact provides such an analysis of the United States UI system by comparing its effects on consumptionsmoothing among the unemployed with its effects on unemployment duration. Using conventional measures of workers' risk aversion, one can place a value on the reduction in consumption variability that UI enables and compare this value with the lost production due to longer unemployment duration. Gruber (1997) finds under some reasonable assumptions that UI replacement rates of 40-50\% could optimally balance out insurance and lost production effects, although the optimal replacement rate is sensitive to assumptions about risk aversion and the elasticity of unemployment duration with respect to the replacement rate.

\section{Conclusions}


In this paper, I have reviewed theories and evidence on wage-setting institutions and labor market policies in an international comparative context. Many of these policies in effect provide income insurance by: i) reducing the impact of market forces on wages (both over time and across workers); ii) mandating severance pay or enacting barriers against firing workers; iii) paying unemployment benefits; iv) providing training or public employment to the unemployed through ALMPs. Since it is unlikely that an unregulated private sector would provide such insurance, these policies may enhance economic efficiency. Of course, to the extent that unemployment or a misallocation is a result of such measures, these efficiency gains may be offset. Overall, Scandinavia and Central Europe follow distinctively more interventionist policies than the English speaking countries in the Northern Hemisphere. Possible explanations for such differences were discussed, including vulnerability to external market forces and ethnic homogeneity.

I then reviewed evidence on the impacts of these policies and institutions. While the interventionist model appears to cause low levels of wage inequality and high levels of job security to incumbent workers, it also in some cases leads to the relegation of new entrants (disproportionately women, youth and immigrants) as well as the less skilled to temporary jobs or unemployment. Making labor markets more flexible, then, could bring these groups into the regular labor market to a greater extent, at the expense of higher levels of economic insecurity for incumbents and higher levels of wage inequality. The Danish model of loosening employment protections while providing relatively generous UI benefits with strict job search requirements holds out the possibility of reducing barriers for new entrants and the less skilled while maintaining some level of income insurance. Whether such policies could be enacted in less ethnically-homogeneous countries is an open question. 


\section{References}

Abowd, J. M., Kramarz, F., Lemieux, T., \& Margolis, D. N. (2000). Minimum wages and youth employment in France and the United States. In D. G Blanchflower \& R. B. Freeman (Eds.). Youth employment and joblessness in advanced countries. Chicago: University of Chicago Press, 427-472

Agell, J. \& Lommerud, K. E. (1992). Union egalitarianism as income insurance. Economica, 59(235), 295-310.

Alesina, A. \& Glaeser, E. L. (2004). Fighting poverty in the U.S. and Europe: A world of difference. New York: Oxford University Press.

Algan, Y., Cahuc, P. \& Zylberberg, A. (2002). Public employment and labour market performance. Economic Policy, 34, 7-41.

Arulampalam, W., Booth, A. L., \& Bryan, M. L. (2007). Is there a glass ceiling over Europe? Exploring the gender pay gap across the wage distribution. Industrial \& Labor Relations Review, 60(2), 163-186.

Atkinson, A. B. \& Micklewright, J. (1991). Unemployment compensation and labor market transitions: A critical review. Journal of Economic Literature, 29(4), 1679-1727.

Andersen, T. M. \& Svarer, M. (2007). Flexicurity-labor market performance in Denmark. CESifo Economic Studies, 53(3), 389-429.

Autor, D. H., Donohue III, J. J., \& Schwab, S. J. (2006). The costs of wrongful-discharge laws. The Review of Economics and Statistics, 88(2), 211-231.

Autor, D.H. \& Houseman, S.N. (forthcoming). Do temporary help jobs improve labor market outcomes for low-skilled workers? Evidence from 'Work First.' American Economic Journal: Applied Economics.

Autor, D. H., Kerr, W. R., \& Kugler, A. D. (2007). Does employment protection reduce productivity? Evidence from US States. Economic Journal, 117(521), F189-F217.

Baker, M. \& Milligan, K. (2008). How does job-protected maternity leave affect mothers' employment? Journal of Labor Economics, 26(4), 655-691.

Bell, L. A. (1997). The impact of minimum wages in Mexico and Colombia. Journal of Labor Economics, 15(3, pt.2), S102-S135.

Bertola, G. (1992). Labor turnover costs and average labor demand. Journal of Labor Economics, 10(4), 389-411.

Bertola, G. Blau, F. D., \& Kahn, L. M. (2007). Labor market institutions and demographic employment patterns. Journal of Population Economics, 20(4), 833-867.

Björklund, A. \& Freeman, R. B. (1997). Generating equality and eliminating poverty, the Swedish way. In R. B. Freeman, R. Topel, \& B. Swedenborg (Eds.). The welfare state in transition: Reforming the Swedish model. Chicago, IL: University of Chicago Press, 3378. 
Blanchard, O. \& Landier, A. (2002). The perverse effects of partial labour market reform: Fixed-term contracts in France. Economic Journal, 112 (480), F214-F244.

Blanchard, O. J. \& Wolfers, J. (2000). The role of shocks and institutions in the rise of European unemployment: The aggregate evidence. Economic Journal, 110(462), C1C33.

Blau, F. D., Ferber, M. A., \& Winkler, A. E. (2010). The economics of women, men and work, $6^{\text {th }}$ ed. Boston: Prentice Hall.

Blau, F. D. \& Kahn, L. M. (1992). The gender pay gap: Learning from international comparisons. American Economic Review, 82(2), 533-538.

Blau, F. D. \& Kahn, L. M. (1996). International differences in male wage inequality: Institutions versus market forces. Journal of Political Economy, 104(4), 791-837.

Blau, F. D. \& Kahn, L. M. (2000). Gender and youth employment outcomes: The U.S. and West Germany, 1984-91. In D. G Blanchflower \& R. B. Freeman (Eds.). Youth employment and joblessness in advanced countries. Chicago: University of Chicago Press, 107-167.

Blau, F. D. \& Kahn, L. M. (2003). Understanding international differences in the gender pay gap. Journal of Labor Economics, 21(1), 106-144.

Blau, F. D. \& Kahn, L. M. (2005). Do cognitive test scores explain higher U.S. wage inequality? The Review of Economics and Statistics, 87(1), 184-193.

Blau, F. D. \& Kahn, L. M. (2008). Women's work and wages. In S. Durlauf \& L. Blume (Eds.). The new Palgrave dictionary of economics, 2nd edition, Vol. 8. New York: Palgrave Macmillan, 762-772.

Boeri, T. \& Garibaldi, P. (2007). Two tier reforms of employment protection: A honeymoon effect?" Economic Journal, 117(521), F357-F385.

Booth, A. L., Dolado, J. J., \& Frank, J. 2002. Symposium on temporary work introduction. Economic Journal, 112(480), F181-F188.

Booth, A. L., Francesconi, M., \& Frank, J. (2002). Temporary jobs: Stepping stones or dead ends. Economic Journal, 112 (480), F189-F213.

Brügemann, B. (2007). Employment protection: Tough to scrap or tough to get? Economic Journal, 117(521), F386-F415.

Calmfors, L. \& Driffill, J. (1988). Centralization of wage bargaining. Economic Policy, 3, 1461.

Carling, K., Holmlund, B., \& Vejsiu, A. (2001). Do benefit cuts boost job finding? Swedish evidence from the 1990s. Economic Journal, 111(474), 766-790.

Cameron, D. R. (1978). The evolution of the public economy: A comparative analysis. American Political Science Review, 72(4), 1243-1261.

Card, D., Kluve, J., \& Weber, A. (2009). Active labor market policy evaluations: A Metaanalysis. IZA Discussion Paper No. 4002. Bonn: IZA. 
Card, D., Kramarz, F., \& Lemieux, T. (1999). Changes in the relative structure of wages and employment: A comparison of the United States, Canada, and France. Canadian Journal of Economics, 32(4), 843-77.

Card, D. \& Krueger, A. B. (1995). Myth and measurement: The new economics of the minimum wage. Princeton, NJ: Princeton University Press.

Davis, S. J. \& Henrekson, M. (2005). Wage-setting institutions as industrial policy. Labour Economics, 12(3), 345-377.

DiNardo, J. Fortin, N. M., \& Lemieux, T. (1996). Labor market institutions and the distribution of wages, 1973-1992: A semiparametric approach. Econometrica, 64(5), 1001-44.

Dixon, S. (1998). The growth of earnings inequality 1984-1997: Trends and sources of change. Paper presented at the Eighth Conference on Labour, Employment, and Work, Victoria University of Wellington.

Dolado, J., Kramarz, F., Machin, S., Manning, A., Margolis, D., \& Teulings, C. (1996). The economic impact of minimum wages in Europe. Economic Policy, 23, 319-72.

Edin, P.-A. \& Topel. R. (1997). Wage policy and restructuring: The Swedish labor market since 1960.” In R. B. Freeman, R. Topel, \& B. Swedenborg (Eds.). The welfare state in transition: Reforming the Swedish model. Chicago, IL: University of Chicago Press, $155-201$.

Ehrenberg, R.G. \& Smith, R. S. (2006). Modern labor economics, $9^{\text {th }}$ ed. Boston: AddisonWesley.

Erickson, C. L. \& Ichino, A. C. (1995). Wage differentials in Italy. In R. B. Freeman \& L. F. Katz (Eds.). Differences and changes in wage structures. Chicago: University of Chicago Press, 265-305.

Farber, H. S. (1986). The analysis of union behavior. In O. Ashenfelter \& R. Layard (Eds.). Handbook of labor economics, Vol. II. Amsterdam: North-Holland, 1039-89.

Forslund, A. \& Krueger, A. B. (1997). An evaluation of the Swedish active labor market policy: New and received wisdom." In R. B. Freeman, R. Topel, \& B. Swedenborg (Eds.). The welfare state in transition: Reforming the Swedish model. Chicago, IL: University of Chicago Press, 267-298.

Freeman, R. B. (1982). Union wage practices and wage dispersion within establishments. Industrial \& Labor Relations Review, 36(1), 3-.21.

Gruber, J. (1997). The consumption smoothing benefits of unemployment insurance. American Economic Review, 87(1), 192-205.

Gupta, N. D., Smith, N., \& Verner, M. (2008). The impact of Nordic countries' family friendly policies on employment. Review of Economics of the Household, 6(1), 65-89.

Han, W.-J., Ruhm, C., \& Waldfogel, J. (2007). Parental leave policies and parents' employment and leave-taking. IZA Discussion Paper No. 3244. Bonn: IZA.

Hunt, J. (1995). The effect of unemployment compensation on unemployment duration in Germany. Journal of Labor Economics, 13(1), 88-120. 
Ichino, A., Mealli, F., \& Nannicini, T. (2005). Temporary work agencies in Italy: a springboard toward permanent employment? Giornale degli Economisti e Annali di Economia, 64(1), 1-27.

Kahn, L. M. (1998). Against the wind: Bargaining recentralisation and wage inequality in Norway, 1987-1991. Economic Journal, 108(448), 603-645.

Kahn, L. M. (2007). The impact of employment protection mandates on demographic temporary employment patterns: International microeconomic evidence. Economic Journal, 117 (521), F333-F356.

Kahn, L. M. (2008). The impact of wage-setting institutions on the incidence of public employment in the OECD: 1960-1998. Industrial Relations, 47(3), 329-354

Kahn, L. M. (2010). Employment protection reforms, employment and the incidence of temporary jobs in Europe: 1996-2001. Labour Economics, 17(1), 1-15.

Katzenstein, P. J. (1985). Small states in world markets: Industrial policy in Europe. Ithaca, NY: Cornell University Press.

Klepinger, D. H., Johnson, T. R., \& Joesch, J. M. (2002). Effects of unemployment insurance work-search requirements: The Maryland experiment. Industrial \& Labor Relations Review, 56(1), 3-22.

Koeniger, W., Leonardi, M., \& Nunziata, L. (2007). Labor market institutions and wage inequality. Industrial \& Labor Relations Review, 60(3), 340-356.

Krueger, A. B. \& Pischke, J.-S.. (1998). Observations and conjectures on the U.S. employment miracle." In German-American Academic Council (Ed.). Third public GermanAmerican Academic Council symposium: Labor markets in the USA and Germany. Bonn: German-American Academic Council, 99-126.

Kugler, A. (1999). The impact of firing costs on turnover and unemployment: Evidence from the Colombian labour market reform. International Tax and Public Finance Journal, 6(3), 389-410.

Kugler, A., Jimeno, J. F., \& and Hernanz, V. (2005). Employment consequences of restrictive permanent contracts: Evidence from Spanish labor market reforms. Working paper, University of Houston.

Kugler, A. \& Pica, G. 2008. Effects of employment protection on worker and job flows: Evidence from the 1990 Italian reform. Labour Economics, 15(1), 78-95.

Lazear, E. P. (1990). Job security provisions and employment. Quarterly Journal of Economics, 105(3), 699-726.

Machin, S. \& Manning, A. (1994). The effects of minimum wages on wage dispersion and employment: Evidence from the U.K. Wage Councils. Industrial \& Labor Relations Review, 47(2), 319-29.

MacLeod, W. B. \& Nakavachara, V. (2007). Can wrongful discharge law enhance employment? Economic Journal, 117(521), F218-F278. 
Manacorda, M. (2004). Can the Scala Mobile explain the fall and rise of earnings inequality in Italy? A semiparametric analysis. Journal of Labor Economics, 22(3), 585-613.

Manning, A. (2003). Monopsony in motion: Imperfect competition in labor markets. Princeton: Princeton University Press.

Marinescu, I. (2009). Job security legislation and job duration: Evidence from the United Kingdom. Journal of Labor Economics, 27(3), 465-486.

Meyer, B. D. (1995). Lessons from the U. S. unemployment insurance experiments. Journal of Economic Literature, 33(1), 91-131.

Nickell, S. \& Layard, R. (1999). Labor market institutions and economic performance. In O. Ashenfelter \& D. Card (Eds.). Handbook of labor economics, volume 3C. Amsterdam: North-Holland, 3029-3084.

OECD. (2002). Employment outlook: 2002. Paris: OECD.

OECD. (2004). Employment outlook: 2004. Paris: OECD.

OECD. (2008). Employment outlook: 2008. Paris: OECD.

OECD. (2010). Employment outlook: 2010. Paris: OECD.

Olivetti, C. \& Petrongolo, B. (2008). Unequal pay or unequal employment? A cross-country analysis of gender gaps. Journal of Labor Economics, 26(4), 621-654.

Ondrich, J., Spiess, C. K., Yang, Q., \& Wagner, G. G. (2003). The liberalization of maternity leave policy and the return to work after childbirth in Germany. Review of Economics of the Household, 1(1-2), 77-110.

Picchio, M. \& Mussida, C. (2010). Gender wage gap: A semi-parametric approach with sample selection correction. IZA Discussion Paper No. 4783. Bonn: IZA.

Rodrik, D. (1998). Why do more open economies have bigger governments? Journal of Political Economy, 106(5), 997-1032.

Rothschild, M. \& Stiglitz, J. (1976). Equilibrium in competitive insurance markets: An essay on the economics of imperfect information. Quarterly Journal of Economics, 90(4), 629649.

Ruhm, C. J. (1998). The economic consequences of parental leave mandates: Lessons from Europe. Quarterly Journal of Economics, 113(1), 285-317.

Summers, L. H. (1989). Some simple economics of mandated benefits. American Economic Review, 79(2), 117-183.

Summers, L. H., Gruber, J., \& Vergara, R. (1993). Taxation and the structure of labor markets: The case of corporatism. Quarterly Journal of Economics, 108(2), 385-411.

Wallerstein, M. (1999). Wage-setting institutions and pay inequality in advanced industrial societies. American Journal of Political Science 43, (3), 649-680. 
Table 1: Trade Union Density, Collective Bargaining Coverage, and Coordination Index, Selected Countries, 2000

\begin{tabular}{lccc} 
Country & Union Density (\%) & Collective Bargaining Coverage (\%) & $\begin{array}{c}\text { Coordination Index (1995- } \\
\text { 2000: 1=low, 5=high) }\end{array}$ \\
\hline Denmark & 74 & $80+$ & 4 \\
Finland & 76 & $90+$ & 5 \\
Norway & 54 & $70+$ & 4.5 \\
Sweden & 79 & $90+$ & 3 \\
France & 10 & $90+$ & 2 \\
Germany & 25 & 68 & 4 \\
Italy & 35 & $80+$ & 4 \\
Spain & 15 & $80+$ & 3 \\
Canada & 28 & 32 & 1 \\
United Kingdom & 31 & $30+$ & 1 \\
United States & 13 & 14 & 1 \\
\hline
\end{tabular}

Source: OECD (2004), pp. 145, 151. Union density is the percentage of wage and salary workers who are union members. Coverage is the fraction of wage and salary workers covered by collective bargaining. 
Table 2: Employment Protection Regulation Strictness, 2003 ( $0=$ no regulation up to 6$)$

\begin{tabular}{lcr} 
Country & Regular Employment & Temporary Employment \\
\hline Denmark & 1.5 & 1.4 \\
Finland & 2.2 & 1.9 \\
Norway & 2.3 & 2.9 \\
Sweden & 2.9 & 1.6 \\
France & 2.5 & 3.6 \\
Germany & 2.7 & 1.8 \\
Italy & 1.8 & 2.1 \\
Spain & 2.6 & 3.5 \\
Canada & 1.3 & 0.3 \\
United Kingdom & 1.1 & 0.4 \\
United States & 0.2 & 0.3 \\
\hline
\end{tabular}

Source: OECD (2004), p. 117. 
Table 3: Further Labor Market Policy Characteristics--Unemployment Insurance (UI), Minimum Wages, and Active Labor Market Programs (ALMPs), and Paid Parental Leave

\begin{tabular}{|c|c|c|c|c|c|}
\hline Country & $\begin{array}{c}\text { UI Net } \\
\text { Replacement } \\
\text { Ratio (\%, 2004) }\end{array}$ & $\begin{array}{l}\text { Maximum UI } \\
\text { Benefit Duration } \\
\text { Ratio (months, } \\
\text { 2004) }\end{array}$ & $\begin{array}{c}\text { Statutory } \\
\text { Minimum Wage } \\
\text { as Fraction of } \\
\text { Median Wage } \\
\text { (2004) }\end{array}$ & $\begin{array}{l}\text { Spending on } \\
\text { ALMPs as a } \\
\text { Percentage of } \\
\text { GDP (2008) }\end{array}$ & $\begin{array}{c}\text { Full Time } \\
\text { Equivalent Weeks } \\
\text { of Paid Parental } \\
\text { Leave, Couples } \\
\text { (2008) }\end{array}$ \\
\hline Denmark & 70 & 48 & & 1.35 & 19.6 \\
\hline Finland & 70 & 23 & & 0.82 & 33.0 \\
\hline Norway & 68 & 36 & & 0.56 & 44.0 \\
\hline Sweden & 75 & 28 & & 0.99 & 46.8 \\
\hline France & 75 & 30 & 0.54 & 0.81 & 23.4 \\
\hline Germany & 69 & 12 & & 0.81 & 42.0 \\
\hline Italy & 54 & 6 & & 0.45 & 25.1 \\
\hline Spain & 67 & 21 & 0.29 & 0.73 & 26.7 \\
\hline Canada & 63 & 9 & 0.41 & 0.30 & 28.6 \\
\hline United Kingdom & 54 & 6 & 0.44 & 0.32 & 12.4 \\
\hline United States & 54 & 6 & 0.31 & 0.17 & 0.0 \\
\hline
\end{tabular}

Sources: OECD (2006, pp. 60, 87), www.ssa.gov (for Denmark's UI benefit duration), OECD (2010, pp. 298-304), and Ray, Gornick and Schmitt (2008, p. 13). ALMP data refer to 2008-9 for Canada and the United States, 2007-8 for the United Kingdom, and 2007 for Norway. 
Table 4: Labor Utilization, 2009

\begin{tabular}{|c|c|c|c|c|c|c|c|c|c|c|}
\hline \multicolumn{9}{|c|}{ A. Employment-Population Ratio (\%) } & \multicolumn{2}{|c|}{ B. Fraction Part Time (\%) } \\
\hline & \multicolumn{4}{|c|}{ Men } & \multicolumn{4}{|c|}{ Women } & \multirow[b]{2}{*}{ Men } & \multirow[b]{2}{*}{ Women } \\
\hline & Age $15-64$ & Age $15-24$ & Age $25-54$ & Age $55-64$ & Age 15-64 & Age $15-24$ & Age $25-54$ & Age 55-64 & & \\
\hline Denmark & 78.3 & 63.6 & 87.2 & 64.1 & 73.1 & 63.7 & 82.9 & 50.9 & 13.6 & 24.8 \\
\hline Finland & 68.9 & 35.6 & 84.4 & 54.7 & 67.9 & 41.6 & 80.4 & 56.5 & 8.7 & 15.9 \\
\hline Norway & 78.4 & 52.0 & 88.3 & 72.8 & 74.4 & 54.4 & 83.5 & 64.6 & 11.3 & 30.4 \\
\hline Sweden & 74.1 & 37.3 & 86.9 & 73.3 & 70.2 & 38.8 & 81.9 & 66.8 & 10.0 & 19.8 \\
\hline France & 68.0 & 32.1 & 87.6 & 41.4 & 59.8 & 28.1 & 76.8 & 36.7 & 5.1 & 22.4 \\
\hline Germany & 75.5 & 48.6 & 86.1 & 63.8 & 65.2 & 44.4 & 75.4 & 48.6 & 8.0 & 38.1 \\
\hline Italy & 68.6 & 26.1 & 84.7 & 46.7 & 46.4 & 17.0 & 59.1 & 25.4 & 5.9 & 30.5 \\
\hline Spain & 67.5 & 32.4 & 77.3 & 56.7 & 53.5 & 29.1 & 63.8 & 32.3 & 4.4 & 21.4 \\
\hline Canada & 74.0 & 53.6 & 83.5 & 62.3 & 69.1 & 57.1 & 77.2 & 53.1 & 11.9 & 27.0 \\
\hline United Kingdom & 75.7 & 52.8 & 85.4 & 66.1 & 65.6 & 51.4 & 74.4 & 49.3 & 10.9 & 38.8 \\
\hline \multirow[t]{4}{*}{ United States } & 72.0 & 46.7 & 81.5 & 65.2 & 63.4 & 47.0 & 70.2 & 56.4 & 9.2 & 19.2 \\
\hline & \multicolumn{8}{|c|}{ C. Harmonized Unemployment Rate } & & \\
\hline & \multicolumn{5}{|c|}{ Men } & \multicolumn{2}{|c|}{ Women } & & & \\
\hline & Age $15-64$ & Age $15-24$ & Age $25-54$ & Age $55-64$ & Age 15-64 & Age $15-24$ & Age $25-54$ & Age 55-64 & & \\
\hline Denmark & 6.7 & 12.4 & 5.7 & 5.3 & 5.4 & 9.9 & 4.7 & 3.9 & & \\
\hline Finland & 9.1 & 24.5 & 7.1 & 7.1 & 7.6 & 18.8 & 6.1 & 5.5 & & \\
\hline Norway & 3.7 & 10.3 & 2.9 & 1.5 & 2.7 & 8.0 & 2.0 & 0.6 & & \\
\hline Sweden & 8.8 & 26.3 & 6.4 & 5.8 & 8.1 & 23.7 & 6.0 & 4.6 & & \\
\hline France & 8.9 & 23.1 & 7.2 & 6.5 & 9.3 & 21.5 & 8.2 & 6.0 & & \\
\hline Germany & 8.2 & 12.0 & 7.6 & 8.0 & 7.4 & 9.8 & 6.9 & 8.0 & & \\
\hline Italy & 6.9 & 23.3 & 5.9 & 3.7 & 9.3 & 28.7 & 8.5 & 2.8 & & \\
\hline Spain & 17.8 & 39.1 & 16.2 & 11.3 & 18.5 & 36.4 & 16.9 & 13.3 & & \\
\hline Canada & 9.6 & 18.0 & 8.0 & 8.0 & 7.1 & 12.4 & 6.1 & 5.7 & & \\
\hline United Kingdom & 8.9 & 21.7 & 6.8 & 6.0 & 6.5 & 15.6 & 5.2 & 2.8 & & \\
\hline United States & 10.5 & 20.1 & 9.2 & 7.2 & 8.2 & 14.9 & 7.2 & 6.0 & & \\
\hline
\end{tabular}

Source: OECD (2010), pp. 272-3, 277-82, and 286. Part time work is defined as a work week of less than 30 hours and is expressed as a percentage of employment. 
Table 5: Harmonized Unemployment Rates by Immigrant Status and Gender, 2007

\begin{tabular}{|c|c|c|c|c|}
\hline Country & Native Born Men & Foreign-Born Men & Native-Born Women & Foreign-Born Women \\
\hline Denmark & 3.0 & 8.6 & 3.8 & 7.9 \\
\hline Finland & 6.5 & 12.0 & 6.9 & 17.4 \\
\hline Norway & 3.1 & 8.9 & 3.0 & 7.7 \\
\hline Sweden & 5.1 & 11.7 & 5.5 & 12.6 \\
\hline France & 7.2 & 11.9 & 7.6 & 15.1 \\
\hline Germany & 7.7 & 14.9 & 8.0 & 13.5 \\
\hline Italy & 4.9 & 5.3 & 7.6 & 11.4 \\
\hline Spain & 6.0 & 8.3 & 10.5 & 12.6 \\
\hline Canada & 6.7 & 6.1 & 6.2 & 7.9 \\
\hline United Kingdom & 5.4 & 6.9 & 4.4 & 8.5 \\
\hline United States & 5.4 & 4.8 & 4.3 & 4.0 \\
\hline
\end{tabular}

Source: Country Notes to OECD, Immigration Outlook 2009:

http://www.oecd.org/document/48/0,3343,en_2649_33931_44060528_1_1_1_1,00.html Data for Canada and Norway refer to 2006. 
Table 6: Incidence of Temporary Employment, 2000 and 2009 (\% of dependent employment)

\section{A. 2000}

\begin{tabular}{lccccc} 
Country & Men & Women & Age 15-24 & Age 25-54 & Age 55+ \\
\hline Denmark & 8.8 & 11.7 & 30.6 & 6.5 & 5.1 \\
Finland & 14.5 & 20.9 & 49.5 & 14.3 & 5.1 \\
Norway & 7.8 & 11.8 & 33.6 & 8.6 & 5.2 \\
Sweden & 12.3 & 16.9 & 41.3 & 10.5 & 7.5 \\
France & 14.3 & 15.7 & 34.8 & 6.6 & 3.0 \\
Germany & 12.5 & 13.1 & 38.9 & 6.1 & 3.8 \\
Italy & 8.8 & 12.2 & 14.7 & 5.4 & 5.5 \\
Spain & 30.6 & 34.6 & 67.4 & 25.2 & 11.8 \\
Canada & 11.8 & 13.3 & 29.5 & 8.8 & 10.5 \\
United Kingdom & 5.9 & 7.7 & 12.0 & 4.9 & 5.8 \\
United States & 3.9 & 4.2 & 8.1 & 3.2 & 3.8 \\
\hline
\end{tabular}

B. 2009

\begin{tabular}{lcccc} 
Country & Total & Women & Age 15-24 & Age 25-54 \\
& & & & \\
\hline Denmark & 8.9 & 9.6 & 23.6 & 6.5 \\
Finland & 14.6 & 18.4 & 39.0 & 12.4 \\
Norway & 9.2 & 13.1 & 32.4 & 6.8 \\
Sweden & 15.3 & 17.6 & 53.4 & 11.1 \\
France & 13.5 & 15.0 & 51.2 & 9.7 \\
Germany & 14.5 & 14.6 & 57.2 & 9.3 \\
Italy & 12.5 & 14.6 & 44.4 & 10.7 \\
Spain & 25.4 & 27.3 & 55.9 & 24.2 \\
Canada & 12.5 & 12.9 & 27.8 & 9.2 \\
United Kingdom & 5.7 & 6.1 & 11.9 & 4.3 \\
United States & 4.2 & 4.2 & 8.1 & 3.5 \\
\hline
\end{tabular}

Sources: OECD (2002, p. 138); OECD (2010, pp. 289-90). Data refer to 1997 and 2009 for Canada and 2001 and 2005 for the US. 
Table 7: Wage Inequality and the Gender Pay Gap, 2008

\begin{tabular}{lccc} 
Country & $90: 50$ Wage Ratio & $50: 10$ Wage Ratio & Female/Male Pay Ratio \\
\hline Denmark & 1.74 & 1.57 & 0.88 \\
Finland & 1.76 & 1.46 & 0.79 \\
Norway & 1.46 & 1.56 & 0.91 \\
Sweden & 1.66 & 1.37 & 0.85 \\
France & 1.98 & 1.47 & 0.88 \\
Germany & 1.72 & 1.93 & 0.75 \\
Italy & 1.74 & 1.55 & 0.94 \\
Spain & 1.98 & 1.66 & 0.88 \\
Canada & 1.88 & 2.00 & 0.80 \\
United Kingdom & 1.98 & 1.83 & 0.79 \\
United States & 2.34 & 2.09 & 0.80 \\
\hline
\end{tabular}

Sources: OECD (2010), p. 295, and unpublished tabulations from the OECD for the Italian gender pay gap, kindly supplied by Pascal Marianna. Data for France are from 2007. Wages are defined as gross earnings of full-time wage and salary workers. The gender pay gap is defined as the ratio of median earnings of women divided by median earnings of men, except for Italy, where the gender pay gap is defined as the ratio of female to male median hourly earnings for workers who usually work at least 30 hours per week. 